\title{
Proffesionalism in the Post Soeharto Indonesian Military
}

\author{
Muradi $^{1}$ \\ ${ }^{1}$ Department of Government, Faculty of Social and Political Sciences, University of Padjadjaran, Bandung West \\ Java Indonesia \\ Correspondence: Muradi, Department of Government, Faculty of Social and Political Sciences, University of \\ Padjadjaran, J1. Ir. Soekarno KM 21, Jatinangor, Bandung West Java Indonesia. Tel: 62-8-1155-5613. E-mail: \\ muradi@unpad.ac.id; muradiclark@gmail.com
}

Received: September 17, 2017

doi:10.5539/jpl.v10n5p124
Accepted: September 28, 2017 Online Published: November 29, 2017

URL: https://doi.org/10.5539/jpl.v10n5p124

\begin{abstract}
This paper will discuss the changing role of the military in criminal activity during the Reform Era which was affected by strict regulations, the supervision of institutions and the government's commitment to meet the welfare of the soldiers, with criminal activities referring to activities such as illegal economic activities, extortion, as well as drug and human trafficking. This paper will also analyze the ongoing criminal activity in the military, which mostly originates from personal interest rather than in the interest of the institution. This paper also describes the competition between military and police increasing criminal activities in order to seize illegal financial income potential. This paper will also analyze the methods of Post-Suharto military involvement in criminal activities.
\end{abstract}

Keywords: the Indonesian military, criminal, activities, dual functions, reform era

\section{Introduction}

The Indonesia National Armed Forces (Tentara Nasional Indonesia-TNI) was not fully prepared to cope with a low defense budget at the beginning of its establishment and had to engage in combat operations to defend Indonesia against strong enemies. The government was also not able to support the military budget at the beginning of independence. Hence, the TNI had to accumulate all available resources to support the organization and its members independently. ${ }^{1}$ The insurgents and militants was join in illegal economic activities to fund military operations. At the beginning of the independence, almost all insurgents and militants had to find their own sources of revenue to finance military operations against the Netherlands, where smuggling rubber, copra, oil and opium were the easiest way. ${ }^{2}$

The TNI had an influential presence and played an important role in the Republic of Indonesia during Soeharto's New Order regime. The TNI, together with the Functional Party (Partai Golongan Karya, GOLKAR) and government bureaucrats, was an integral part of Soeharto's New Order Regime and was known as ABG (ABRI', Golkar and Bureaucracy ${ }^{4}$ ). The TNI served as the vanguard of Soeharto's New Order Regime for 32 years. The influence of the TNI was made even stronger due to Soeharto's policies that took advantage of the TNI's network.

Soeharto's policies protecting the development of his New Order regime at the expense of human, civil, and political rights. An example of a political crime was the Petrus Killings (Penembakan Misterius-Petrus), where the TNI and POLRI arrested and murdered political activists and street criminals. The TNI and POLRI's actions in criminalizing citizens was considered effective, as the Petrus Killings reduced crime levels and silenced the

\footnotetext{
${ }^{1}$ For example, see Jaleswari Pramodhawardani \& Andi Widjajanto (ed). (2007). Bisnis Serdadu: Ekonomi Bayangan). Jakarta: The Indonesian Institute. See also Muradi. et al. (2007). Especially chapter 4.

${ }^{2}$ For example, see Lex Rieffel \& Jaleswari Pramodhawardani. (2007). Menggusur Bisnis Militer: Tantangan Pembiayaan TNI Melalui $A P B N$. (Especially Chapter 1) .Bandung: Mizan.

${ }^{3}$ ABRI (Angkatan Bersenjata Republik Indonesia) is the name of the organisation where the Indonesia Armed Forces (TNI) and the Indonesia National Police (POLRI) were under the same organisation from the 1960s until its dispersal in 1999. President Habibie separated the TNI and the POLRI from ABRI in year 2000. Bhakti, Ikrar Nusa (2004).Relasi TNI dan Polri Dalam Penanganan Keamanan Dalam Negeri 2000-2004. (Pp. 9-14). Jakarta: LIPI-P2I.

${ }^{4}$ Sundhaussen, Ulf. (1982). Road to Power: Indonesian Military Politics 1945-1967. Especially chapter 1. Oxford: Oxford University Press.
} 
opposition of the New Order Regime. ${ }^{5}$ The TNI was involved in a "cleansing operation" against the members and supporters of Indonesia Communist Party (PKI), and was also allegedly involved in the 30 September 1965 tragedy. ${ }^{6}$ However, there had been a change in the motive of the criminal acts by the TNI during and after the New Order Regime.

Political reform brought on by the fall of Soeharto caused the TNI to lose its direction. The TNI was also under pressure by strong political policies which demanded the change of Dwifungsi (Dual Function) and the separation of the Indonesian National Police (POLRI) from ABRI. In the Post-Soeharto era, the TNI transformed into a professional armed forces. Under the Law No.3/2002 on National Defense and Law No.34/2004 on the TNI, the TNI was no longer allowed to be involved in economic and political activities, and were only allowed to be involved in matters related to National Defense. Unfortunately, associations between the TNI and criminal activities consisting of economic and political crimes exist. During the New Order Regime, the TNI conducted criminal acts in order to protect national interest or to accumulate resources for the TNI's operational needs. Conversely, in the Post-Soeharto era, criminal acts were conducted to pursue the personal interests of the TNI members rather than to protect national interest.

This article will analyze the changing role of the TNI in criminal activities during the Reform Order, which were mainly caused by strict regulations, a lack of commitment and oversight by the TNI and the government to meet the welfare of the soldiers. In addition, this paper will explore types of criminal activities by the TNI during the Reform Order, such as illegal economic activities, racketeering, drug and human trafficking, which were mainly conducted to further the personal interests of the TNI members rather than national interest. This article will explain the poor competition between the TNI and the POLRI, which resulted in the rise in criminal activities in order to seize potential illegal financial income. Finally, this article will analyze the methods of involvement in criminal activities by the Post-Soeharto TNI.

\section{Indonesia's Military Reforms and the Problems with Its Culture}

The most dominant militaristic character of the TNI is to play a role in every aspect of the Nation. ${ }^{7}$ It certainly relates to one of the basic principles of military culture, which stresses on the existence of the State as part of pride and obligation. The situation evolves when civil politicians are considered incapable of performing their administrative duties and certain politicians introduce ideologies to politicize the TNI publicly. ${ }^{8}$

The role of the military grew stronger during the New Order Regime with the strengthening of the TNI's dwifungsi role in defense and socio-politics. TNI expressed their intention in addressing three national issues, which were social and political stability, social economic stability as well as the TNI's role in the Indonesian revolution as a revolutionary force, a tool for democracy and a means to maintain state security. This gave the TNI an opportunity as a national political force to participate in the administration on the basis of "State Principles of Kinship". ${ }^{9}$

The concept of the TNI's dwifungsi related to the institution of Territorial Command (Komando Teritorial Koter). The institution of Koter was established based on the concept of the Total War doctrine (Sistem Pertahanan Keamanan Rakyat Semesta-Sishankamrata), a doctrine which stated that civilians should be involved in national defense and security as a joint force. This institution was originally established based on the Law of State in Emergency (Staat van Oorlog en Beleg) issued during Soekarno's era. During the New Order era, the institution of Koter was used as a "developing tool" for political stability. The existence of the Koter unit starts from the Provincial Military Command (KODAM) to the Village Unit of Babinsa at the lowest level. ${ }^{10}$

Reforms in the military occurred after 1998 in the post New Order era. The non-defense role and function of the

\footnotetext{
${ }^{5}$ Kroef, Justus M. Van der. (Jul,1985). "Petrus: Pattern of Prophylactic Murder In Indonesia”. Asian Survey, Vol. 25, No.7.

${ }^{6}$ Cribb, Robert. (1990) The Indonesian killings of 1965-1965: studies from Java and Bali Clayton, Vic.: Monash University Centre of Southeast Asian Studies, Monash Papers on Southeast Asia no 21.

${ }^{7}$ For example, see Chrisnandi, Yudi and M.T. Arifin. (2005). Reformasi TNI: Persfektif Baru Hubungan Sipil-Militer di Indonesia. (Pp. 56-69). Jakarta: LP3ES. See also, Honna. (2004). (pp. 34-43).

${ }^{8}$ Furthermore on politics inside the Armed Forces from independence era to Soekarno's Old Order, see Said, Salim (2001). Militer Indonesia dan Politik: Dulu, Kini, dan Kelak. (Especially chapter 1). Jakarta: Sinar Harapan.

${ }^{9}$ for more explain, see Notosusanto, Nugroho. (1970). The Dual Function of the Indonesian Armed Forces Especially Since 1966. (Chapters 2 and 3). Jakarta: Department for Defence and Security. See also Crouch, Harold. (2007). The Army and Politics in Indonesia. (Especially Chapter 2) Jakarta: Equinox.

10 See Agus Widjojo: Kodim Sebaiknya Dihapus. (2017, July 10). Liputan6.com. Retrieved from http://m.liputan6.com/news/read/288445/agus-widjojo-kodim-sebaiknya-dihapus.
} 
TNI had become an obstacle for the democratization process. ${ }^{11}$ Reform inside the TNI began when the military revised the concept of the dwifungsi. There was demand for the TNI to become a professional institution in carrying out their duties to defend and maintain the sovereignty of the NKRI (the Unitary State of Republic of Indonesia), and to not interfere in the social, economic, political and non-defense sectors. ${ }^{12}$

The critical demand for reformation in the TNI was related to the position of the Koter units. These units were considered as obsolete and should be removed in order to improve democracy, as their role and past experience with Koter showed that the units were impediment to the democratization process. There were several reasons for the dispersal of Koter, which were covered by the opinions of Kacung Marijan ${ }^{13}$, Leonard Sebastian ${ }^{14}$, and Jun Honna. ${ }^{15}$

Some military officials had a different perspective. They assumed that the dispersal of the dwifungsi would not necessarily remove territorial command. In their view, it was more important to redesign the role of the institution. According to internal TNI sources, there were territorial functions that the Koter must implement as it was related to defense issues. Four functions could be performed by the Koter: (1) Manage military units under Koter command, (2) Train people as a component of national defense, (3) To prepare and carry out military campaigns defending the area against external threats, and (4) Assist the local government on requests, in particular, requests related to defense issues. ${ }^{16}$

In that context, the role of military as a political force in the post-New Order era had reduced drastically after the abolition of the dwifungsi. It was the responsibility of the military to accept changes as well as respect civil administration. The role of the military in society, politics, and economics had decreased significantly in the civil administration era and the military was committed to focus on national defense.

However, the abolition of the dwifungsi did not remove the military's political influence in the civil society. The TNI still has a powerful bargaining position as a political entity. The military in post-New Order Indonesia is required to play a non-traditional security role in situations where a quick response is required in the civil area. Civic missions refer to instances such as natural disasters and non-military threats, and these emergencies require a fast response for assistance. This was stipulated in the Law of National Defense No. 3/2004 and Law of Indonesia Armed Forces No. 34/2004 which allows the TNI to respond against non-military threats. ${ }^{17}$

The reform of the TNI must be recognized as a change in paradigm of the roles and functions of the TNI officers and personnel, although the military culture of being involved in the politics still strongly exists in the TNI. However, the lack of support from the State Budget is an obstacle in the move to improve military professionalism in the democratic country. Hence, as a result of the state's financial inability in funding the defense sector, funds were usually taken from non-state budget, including funds derived from illegal economic activities. This has become an ongoing activity that has continued functioning under different models and patterns since the early establishment of the TNI to the fall of Soeharto and his New Order, till present day. ${ }^{18}$

Based on the explanation above, the internal TNI military culture guided by duty and honor for the country remains strong, which in turn affects the role and function of the TNI. These conditions tend to make the TNI look ahead and play a dominant role and affected the TNI's interaction with other institutions, especially the police. The TNI desires to compete in many issues, including to control criminal activity. This cause frictions

\footnotetext{
${ }^{11}$ Terence (2000).

${ }^{12}$ For example, see. Mietzner, Marcus. (2006). The Politics of Military Reform in Post-Suharto Indonesia: Elite Conflict, Nationalism, and Institutional Resistance. (Chapters 2 \& 3). Washington DC: East-West Center.

${ }^{13}$ Marijan, Kacung. (2012). Sistem Politik Indonesia; Konsolidasi Demokrasi Pasca-Orde Baru. (Pp. 15-1). Jakarta: Kencana Prenada Media Group.

${ }^{14}$ Sebastian, Leonard.C. (2006). Realpolitik: Indonesia's Use of Military Force. (Chapter 2). Singapore: ISEAS.

${ }^{15}$ Jun Honna, (Apr., 1999). "Military Ideology in Response to Democratic Pressure During the Late Soeharto Era: Political and Institutional Context". Indonesia, Vol.67.

${ }^{16}$ For example, see Haramain, Malik. (2004). Gus Dur, Militer dan Politik. (Pp. 11-129). Yogyakarta: LKiS. . See also Djoko Soeyanto Akan

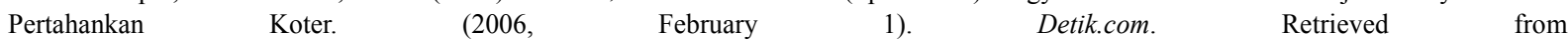
http://news.detik.com/berita/530553/djoko-soeyanto-akan-pertahankan-koter

${ }^{17}$ For example, see Prabowo, Dani. (2015, October 12) Moeldoko: dari pada TNI 'Ngangur, Dikasih Operasi Militer Selain Perang itu Ngaco (2015. Kompas.com from http://nasional.kompas.com/read/2015/10/12/15203491/Moeldoko.Daripada.TNI.Nganggur.Dikasih.Operasi.Militer.Selain.Perang.Itu.Ngaco.

${ }^{18}$ See Iswandi (1998). 2-11. Muradi. et.al. (2007). Metamorfosis Bisnis Militer: Sebaran Bisnis TNIPasca UU TNI Diterbitkan. (Especialyy Chapters 2 and 5. Jakarta: The RIDEP Institution-FES. See also Muradi. (2008). Evaluasi Kinerja TSTB TNI Dalam Pengambilalihan Bisnis TNI. Jakarta: INFID. (pp. 97-112).
} 
between the TNI and the POLRI, resulting in clashes between them ${ }^{19}$. This clash is more than just related to the spirit of esprit de corps, but is also linked to illegal access of economic sources. ${ }^{20}$

\section{Military Budget, Welfare Issues \& Personal Enrichment}

The early shifting point for TNI becoming actively involved in illegal economic activity was due to Soekarno's policy of the nationalization of Dutch owned companies in Indonesia. This was done in consideration of the country's inability to finance the military budget, the minimum salaries of the armed forces, poor housing, and a lack of uniforms and equipment for the soldiers. ${ }^{21}$ This policy was also enacted to reduce the pressure from the military, in particular the Army, and is related to the policy made by the first President of Indonesia. The policy stated that the military was to have great political influence so that Soekarno could find a solution to meet defense needs.

The change of power from Soekarno to Soeharto gave opportunities for personnel of the TNI to commit crimes. As the main pillar of the New Order, the military was free to conduct criminal activities. The TNI's involvement in criminal activities during the New Order era can be categorized into three areas. Firstly, the desire to maintain political and economic stability as long as Soeharto and the New Order are in power. The TNI's involvement in criminal activities was related to political crime against its citizens, as mentioned previously. ${ }^{22}$

The TNI's involvement in criminal activities asserted military as part of the key pillar of the three pillars of the New Order. Robert Cribb had also mentioned in his notes that all arrests, killings and tortures by the military against members and sympathizers who were considered to have links with the Communist Party (PKI) was considered a crime against humanity and it had become a dark part of Indonesia's history ${ }^{23}$. Some other criminal cases involving the military and individuals with political backgrounds were the "Sum Kuning" case in Yogyakarta in 1970, which involved the son of a military official ${ }^{24}$, the Petrus Killings (Penembak Misterius-Petrus) in the $1980 \mathrm{~s}^{25}$, the murder of Marsinah, a labor activist in Sidoarjo during the $1990 \mathrm{~s}^{26}$, and the kidnapping of political and student activists before the fall of Soeharto and his New Order Regime. ${ }^{27}$

Secondly, the reason for the TNI to engage in criminal activities was to meet its requirements, especially with respect to the weapon systems (Alutsista). Indonesia was once dependent to US made weapon systems and had problem when Indonesia faced embargo from USA over human right issue. Brokers and third parties arose to provide or purchase required weapon parts. Crooks in the Armed Forces largely acted as intermediaries for procurement and involved in the maintenance process for the TNI and Ministry of Defence, including opened opportunities for third parties using the pretext to meet the component needed in the maintenance of existing US made weapon systems. ${ }^{28}$

Thirdly, the officers in the TNI were driven by the motive to enrich themselves. The character of the TNI officers in the New Order was similar to "bourgeois officers" that existed during the Soekarno era. There were several criminal activities which involved crook military officers, such as the smuggling of luxury cars conducted by Robby Tjahyadi, which were backed by a number of rogue military officials and the Director General of Customs. $^{29}$

\footnotetext{
${ }^{19}$ For example, see Bentrokan anggota TNI-polisi dikhawatirkan akan terulang. (2015, February 1). bbc.com. Retrieved from http://www.bbc.com/indonesia/berita_indonesia/2015/08/150831_indonesia_polisi_tni

${ }^{20}$ For example, see Pengamat: Bentrok Oknum TNI-Polri Terulang karena Pimpinan Tidak Tegas. (2014, November 20). Kompas.com. Retrieved

http://nasional.kompas.com/read/2014/11/20/13554601/Pengamat.Bentrok.Oknum.TNI-Polri.Terulang.karena.Pimpinan.Tidak.Tegas

${ }^{21}$ (Crouch, 2007). 245-249.

${ }^{22}$ For example, see Ajidharma, Seno Gumira. (2007). Penembak Misterius. (pp. 17-24) Jakarta: Galang Press.

${ }^{23}$ (Cribb, 1990).

${ }^{24}$ Muradi. (2014). Politics and Governance in Indonesia: The Police in the Era of Reformasi. (Pp. 145-149). London: Routledge. See also Fadillah, Ramadhian (2012, May 31). "Hoegeng dan Kisah Pemerkosaan Sum Kuning. Merdeka.com Retrieved from http://www.merdeka.com/peristiwa/hoegeng-dan-kisah-pemerkosaan-sum-kuning.html

${ }^{25}$ Kroef (1985). Ajidharma (2007).

${ }^{26}$ Cooney, Sean. Tim Lindsey. Richard Mitchell and Ying Zhu. (eds). (2002). Law and Labour Market Regulation in east Asia. (Chapter 2). London: Routledge.

${ }^{27}$ More explain, see Aspinall, Edward (2005). Opposing Suharto Compromise, Resistance, and Regime Change in Indonesia. Stanford University: Stanford University Press. And also Kingsbury, Damien (2003). Power Politics and the Indonesian Military. London: Routledge.

${ }^{28}$ For example, see Hendri Firzani and Muchlison Widodo. (2007, November 1). Calo Senjata Ada Dimana-mana. Gatra.com Retrieved from from http://arsip.gatra.com/2007-11-09/artikel.php?id=109306

${ }^{29}$ Pratomo, Angga Yudha. (2013, November 7). "Robby Tjahjadi, Penylundup Paling Fenomena di Indonesia". (Merdeka.com Retrieved from http://www.merdeka.com/peristiwa/robby-tjahjadi-penyelundup-paling-fenomenal-di-indonesia-borok-bea-cukai-2.html
} 
The military's involvement in criminal activities for personal enrichment spread massively, from backing illegal economic activity ${ }^{30}$, drug trafficking ${ }^{31}$, nightclubs ${ }^{32}$, gambling ${ }^{33}$, fuel hoarding ${ }^{34}$, embezzlement and removal of valuable goods ${ }^{35}$, supporting bribery ${ }^{36}$, and engaging hired assassins. ${ }^{37}$ A number of TNI officers were involved in criminal activities, and this indicated a change in the interests of military factions over the future of the Republic. The TNI's involvement in criminal activity was not related to politics, and it had become a reality faced by all TNI leaders. TNI leaders realized that building a professional military was not merely based on strengthening policies and organizations, but also taking care of the welfare of soldiers.

The first and second reason on the presence of criminal activity in the military stressed the importance of strengthening the institution, as it relates directly with the daily activities as combat soldier and also has implications to state politics, such as Nasution's Middle Way and the dwifungsi of the TNI. However, the initiative of the military to participate in criminal activities due to a defense budget that could not meet the needs of the country implied the impatience of its officers even in an era where the military was part of the pillars of power. This affirmed that the TNI's involvement in criminal activity during the New Order era was massive and could not be controlled by Soeharto. The military became an outlet for Indonesians to vent their anger when Soeharto and his New Order regime was ousted from power.

\section{Unscrupulous Commander, Third Parties and Individual Initiatives}

The TNI's involvement in criminal activities during the post-New Order regime was no longer aligned with the interests and purpose of the military institution, but instead served the interests of individual persons in the military. This is largely due to five reasons: Firstly, The TNI's commitment with regard to becoming a professional military has caused it to no longer be involved in criminal activity that pursues organizational interests. After 32 years of being the main pillar of power, the TNI has become disoriented, and should instead return its focus to serving its purpose of state defense. This commitment is reinforced by building a relationship between the TNI and the state in terms of a political relationship, where the military is under civilian control and authority.

Secondly, the commitment of the government to build the capability of Indonesian military of guarding against foreign threats. The government's commitment is reflected in its policies, such as the regular increase of the country's defense budget on a yearly basis. The purpose of this policy is to strengthen weapon system by replacing the old models and to meet the requirements of a Minimum Essential Force (MEF). The state has also gradually increased the budget for the welfare of soldiers in the form of salary increases and bonuses. ${ }^{38}$

Third, there was intense scrutiny by the public and parliament in the form of enacting rules and laws that limited the role of the military to focus only on the country's defense. This acted as a deterrent for military officers and encourages them to abide by these rules, as violation of the rules may result in the officer's dismissal from the institution or criminal prosecution. ${ }^{39}$

Fourth, after the military's disassociation from the Police, the TNI attempts to maintain a good image in

\footnotetext{
${ }^{30}$ Baiquni, Ahmad. (2014, October 14). "Investigasi Batam: TNI Jadi Beking Buat cari Duit Tambahan. Merdeka.com Retrieved from http://www.merdeka.com/peristiwa/investigasi-batam-tni-jadi-beking-buat-cari-duit-tambahan.html

31 Joko Santoso Harus Tertibkan TNI yang Jadi Beking. (2007, December 18. Detik.com Retrieved from http://news.detik.com/berita/868429/joko-santoso-harus-tertibkan-tni-yang-jadi-beking

${ }^{32}$ Sari, Lukman Diah. (2015, September 9). "Budi Waseso Akan Hadapi Beking Tempat Hiburan Malam”. Metrotvnews.com. Retrieved from http://news.metrotvnews.com/read/2015/09/09/167738/budi-waseso-akan-hadapi-beking-tempat-hiburan-malam

33 Oknum TNI Beking Judi Sabung Ayam Digrebek Polisi. (2015, December 30). Rimanews.com. Retrieved from http://nasional.rimanews.com/peristiwa/read/20151230/253109/Oknum-TNI-Beking-Judi-Sabung-Ayam-Digerebek-Polisi

34 Dua Anggota TNI Kedapatan Menimbun BBM. (2012, June 27). (Liputan6.com. Retrieved from http://news.liputan6.com/read/416220/dua-anggota-tni-kedapatan-menimbun-bbm

35 Penggelapan Gula Terbongkar, Dua Oknum Anggota TNI Terlibat. (2015, June 10). Sorotpurworejo.com. Retrieved from http://www.sorotpurworejo.com/berita-purworejo-1327-penggelapan-gula-terbongkar-dua-oknum-anggota-tni-terlibat.html

${ }^{36}$ Armenia, Resti (2015, December 2). “TNI Yakin Pabrik Pembuat Helikopter VVIP AW Tak Terlibat Suap”. Cnnindonesia.com.Retrieved from http://www.cnnindonesia.com/nasional/20151202134554-20-95462/tni-yakin-pabrik-pembuat-helikopter-vvip-aw-tak-terlibat-suap/

37 Senjata Penembak Dirut Asaba Standar TNI. (2003, July 23). Suaramerdeka.com. Retrieved from http://www.suaramerdeka.com/harian/0307/23/nas13.htm

${ }^{38}$ Iqbal, Muhammad. (2014, October 22). "Presiden Jokowi Minta Renstra Kesejahteraan Prajurit TNI-Polri Disusun". Republika.co.id Restrieved from http://www.republika.co.id/berita/nasional/umum/14/10/22/nduac9-presiden-jokowi-minta-renstra-kesejahteraan-prajurit-tnipolri-disusun

${ }^{39}$ For example, see Wahyudi, Ekky. (2015, October 25). Survey CSIS: TNI Jadi Institusi Paling Dipercaya Publik. cnnindonesia.com. Retrieved from http://www.cnnindonesia.com/nasional/20151025174157-20-87205/survei-csis-tni-jadi-institusi-paling-dipercaya-publik/
} 
comparison to POLRI, BIN and the State Attorney. It is important to assure Indonesians of the role of TNI in post-New Order era. Therefore, after more than 15 years, the military has had a better achievement than the other institutions such as POLRI, BIN and the State Attorney. The only issue that is affecting the image of the TNI is with respect to its clashes with the police, which has happened many times over the last 15 years. Clashes between these two institutions, which was considered by the Indonesians as not in-line with the spirit of esprit de corps, were often caused by the competition for illegal economic access, which were not shared mutually. ${ }^{40}$

Finally, as a combat soldier, the military wants to remain active in the state politics and be involved in talks on the nation's future. ${ }^{41}$ Therefore the military institution is reluctant to conduct activities that are associated with any criminality. Hence, the emphasis is for the TNI to not seek opportunities through criminal activities.

Based on the five reasons above, it can be seen that for the last 15 years, the military, as an institution, no longer engages in criminal activity. Much of the criminal activity was based on personal interest of the military and not the military's interests as an institution, although it is difficult to distinguish between the two factors. However, over the past 15 years, illegal brokerage practices on procurement of defense equipment in the Ministry of Defence was the most challenging practice to be uncovered. ${ }^{42}$

Based on the above explanation, there are three modes of involvement in which rogue military personnel engage in criminal activities in the post-New Order era: firstly, military personnel engaged in criminal activities through personal initiative, for the benefit of a larger group. This method is led by the commanders of a unit in order to create a source of additional income apart from their salaries and improve the welfare of their soldiers. It is difficult to be removed in context of the institution, since it was started through the commanders who made the offer for extra income for soldiers, but the commander explicitly stated that if anything happens then the commander will take the risk. ${ }^{43}$

The second method for military personnel to engage in criminal activity is through a third party. These third parties act as a bridge for TNI personnel to accept jobs that are related to criminal activities. In this method, the agreement is usually between the user, the individual and the third party, whereby the third party assigns military personnel to work, but the user and personnel do not know each other. ${ }^{44}$ In this case, the military personnel are involved in exchanging information, particularly on their activities. This mode also encourages communication between the user and the member of the TNI through meetings, allowing the cultivation of a good relationship. If the personnel moves or is promoted to a commander, this method will fall into the category of the first method as the third party is no longer required.

The third method is related to individual and private connections. This method serves more than just common interest, but private relationship between both the user and the personnel. This mode requires a high level of trust between both parties, such that if a problem were to occur, the issue will be resolved. However, this method is not favored by military personnel due to the direct contact with the user and complications that may arise, which could possibly cause damage to the careers of the military personnel.

Based on analysis above, there are five issues associated with the TNI's involvement in criminal activity during post-Soeharto era: Firstly, the military's involvement in criminal activity is on a personal basis. This is related to the government's commitment in supporting the defense budget and the modernization of the military. Hence, it is hard to find the involvement of the TNI as an institution in criminal activity as seen in the early days of independence during the era of Soekarno and Soeharto.

Secondly, strict public scrutiny and regulations that emphasize the importance of a professional military that does not source for non-defense funding. In this context, the state receives pressure from the public to improve the country's defense budget to ensure that the TNI does not engage in non-defense activities which could turn into criminal activity.

\footnotetext{
${ }^{40}$ Amarullah, Amril (2014, November 14). "Bentrok TNI-Polri di Lubuk Linggau, Satu Prajurit Diduga Tewas". Okezone.com. Retrieved from http://news.okezone.com/read/2015/11/14/340/1249310/bentrok-tni-polri-di-lubuklinggau-satu-prajurit-diduga-tewas

41 Subkhan. (2012, October 1). TNI Diminta Terlibat Dalam Politik Kenegaraan. Tempo.co Retrieved from http://nasional.tempo.co/read/news/2012/10/01/078433074/TNI-Diminta-Terlibat-dalam-Politik-Kenegaraan

${ }^{42}$ Suparman, Fana. (2015, December 30). "Undang Pimpinan KPK, Kemhan Minta Diceramahi Soal Korupsi”. Beritasatu.com. Retrieved from http://www.beritasatu.com/hukum/336753-undang-pimpinan-kpk-kemhan-minta-diceramahi-soal-korupsi.html

43 Prajurit TNI Diperbolehkan Cari Tambahan. (2017, May 7). Radarpekalongan.com. Retrieved from http://www.radarpekalongan.com/97890/prajurit-tni-diperbolehkan-cari-tambahan/

${ }^{44}$ Prasetya, Eko. (2012, October 4). "Ketika KSAD Jenderal Pramono Bertemu Broker Senjata". Merdeka.com. Retrieved from http://www.merdeka.com/tag/t/tni/ketika-ksad-jenderal-pramono-bertemu-broker-senjata see also Pejabat Kemhan TNI Dituding Jadi Broker. (2012, March 7). Beritasatu.com. Retrieved from http://www.beritasatu.com/politik/35486-pejabat-kemhan-tni-dituding-jadi-broker.html
} 
Thirdly, the involvement of rogue military personnel extends to non-defense activities as well, such as guarding, escorting and trafficking. This is not limited to regular criminal activity, and also includes uncommon criminal activity such as guarding money laundering activities.

Fourth, the competitive relationship between the TNI and the POLRI after the 1999 disassociation, which affects the activities that involved rogue military personnel. Military personnel has to ensure that their involvement were not detected by the police to protect the military's dignity and spirit of esprit de corps.

Fifth, a change of TNI involvement in criminal activity from institutional at the beginning of independence, Soekarno era, and then in the Soeharto era to the limitations involving military personnel, strengthens the military in military culture emphasizes the interests of the institution and the country. Military personnel who are involved in criminal activity will gradually disappear or be later intervened by the strengthening culture of professionalism in the military.

\section{Conclusion}

This paper has explained the change in the involvement of the TNI in criminal activity during the reform era due to tighter rules that limit the movement of the military, along with the government's commitment to meet the welfare of the soldiers. This paper also explained that the military's involvement in criminal activity during the reform era is largely with respect to illegal economic activity, such as racketeering and drug trafficking as explained above. The emphasis is that the TNI's involvement in criminal activity is no longer in the interest of the state or institution, but merely activities initiated by rogue personnel in the TNI. This paper emphasized the changes TNI's involvement in criminal activity which was fueled by unfavorable competition with the POLRI over economic access after the separation of the two institutions. Finally, this paper covered three methods in which the TNI participates in criminal activity after the Soeharto era, namely through personal methods for the benefit of the group, through a third party, and through individual connections and interdependence.

\section{References}

Ajidharma, S. G. (2007). Penembak Misterius (Mysterious Shooters). Jakarta: Galang Press.

Aspinall, E. (2005). Opposing Suharto Compromise, Resistance, and RegimeChange in Indonesia. Stanford University: Stanford University Press.

Azhari, A. F. (2002). Pergulatan Menguak Kebenaran: Penuturan Apa Adanya Seorang Wiranto. Jakarta: IDE Indonesia.

Bhakti, I. N. (2000). Militer dan Politik Kekerasan Orde Baru: Soeharto Berada Dibelakang Peristiwa 27 Juli? Jakarta: LIPI.

Bhakti, I. N. (2004). Relasi TNI dan Polri Dalam Penanganan Keamanan Dalam Negeri 2000-2004. Jakarta: LIPI-P2I.

Chrisnandi, Y., \& Arifin, M. T. (2005). Reformasi TNI: Persfektif Baru Hubungan Sipil-Militer di Indonesia. Jakarta: LP3ES.

Cooney, S., Lindsey, T., Mitchell, R., \& Zhu, Y. (Eds.). (2002). Law and Labour Market Regulation in east Asia. London: Routledge. https://doi.org/10.4324/9780203280003

Cribb, R. (1990). The Indonesian killings of 1965-1965: studies from Java and Bali. Clayton, Vic: Monash University Centre of Southeast Asian Studies, Monash Papers on Southeast Asia No. 21.

Crouch, H. (2007). The Army and Politics in Indonesia. Jakarta: Equinox.

Danusubroto, S. (2003). Sidarto Danusubroto: Dari Ajudan Sampai Wakil Rakyat. Jakarta: Pustaka Sinar Harapan.

Habibie, B. J. (2006). Detik-detik yang Menentukan: Jalan Panjang Indonesia Menuju Demokrasi. Jakarta: the Habibie Center.

Haramain, M. (2004). Gus Dur, Militer dan Politik. Yogyakarta: LKiS.

Honna, J. (1999, April). Military Ideology in Response to Democratic Pressure During the Late Soeharto Era: Political and Institutional Context. Indonesia, 67.

Honna, J. (2004). Military Politics and Democratization in Indonesia. London: Routledge/curzon.

Iswandi. (1998). Bisnis Militer Orde Baru; Keterlibatan ABRI Dalam Bidang Ekonomi dan Pengaruhnya Terhadap Pembentukan Rezim Otoriter. Bandung: Remaja Rosdakarya. 
Kingsbury, D (2003). Power Politics and the Indonesian Military. London: Routledge.

Kroef, J. M. Van der. (1985, July). Petrus: Pattern of Prophylactic Murder In Indonesia. Asian Survey, 25(7). https://doi.org/10.2307/2644242

Lee, T. (2000, Jul-August). The Nature and the Future of Civil-Military Relations in Indonesia. Asian Survey, 40(4). 弗ttps://doi.org/10.2307/3021189

Lesmana, T. (2009). Dari Soekarno Sampai SBY: Intrik \& Lobi Politik Para Penguasa. Jakarta: Kompas Gramedia.

Marijan, K. (2012). Sistem Politik Indonesia; Konsolidasi Demokrasi Pasca-Orde Baru. Jakarta: Kencana Prenada Media Group.

Mietzner, M. (2006). The Politics of Military Reform in Post-Suharto Indonesia: Elite Conflict, Nationalism, and Institutional Resistance. Washington DC: East-West Center.

Mietzner, M. (2009). Military Politics, Islam, and the State in Indonesia: From Turbulent Transition to Democratic Consolidation. Singapore: ISEAS.

Muradi et al. (2007). Metamorfosis Bisnis Militer: Sebaran Bisnis TNI Pasca UU TNI Diterbitkan. Jakarta: The RIDEP Institution-FES.

Muradi. (2008). Evaluasi Kinerja TSTB TNI Dalam Pengambilalihan Bisnis TNI. Jakarta: INFID.

Muradi. (2014). Politics and Governance in Indonesia: The Police in the Era of Reformasi. London: Routledge.

Notosusanto, N. (1970). The Dual Function of the Indonesian Armed Forces Especially Since 1966. Jakarta: Department for Defence and Security.

Pour, J. (2010). Gerakan 30 September: Pelaku, Pahlawan dan Petualang. Jakarta: Kompas Gramedia.

Pramodhawardani, J., \& Widjajanto, A. (Eds.). (2007). Bisnis Serdadu: Ekonomi Bayangan. Jakarta: The Indonesian Institute.

Rieffel, L., \& Pramodhawardani, J. (2007). Menggusur Bisnis Militer: Tantangan Pembiayaan TNI Melalui $A P B N$. Bandung: Mizan.

Said, S. (2001). Militer Indonesia dan Politik: Dulu, Kini, dan Kelak. Jakarta: Sinar Harapan.

Sebastian, L. C. (2006). Realpolitik: Indonesia's Use of Military Force. Singapore: ISEAS.

Sundhaussen, U. (1982). Road to Power: Indonesian Military Politics 1945-1967. Oxford: Oxford University Press.

Tandjung, A. (2007). The Golkar Way: Survival Partai Golkar di Tengah Turbulensi Politik Era Transisi. Jakarta: Gramedia Pustaka Utama.

Tanter, R., Klinken, G., \& Ball, D. (Eds.). (2006). Masters of Terror: Indonesia;s Military and Violence in East Timor. New York: Rowman \& Littlefield Publisher.

\section{Copyrights}

Copyright for this article is retained by the author(s), with first publication rights granted to the journal.

This is an open-access article distributed under the terms and conditions of the Creative Commons Attribution license (http://creativecommons.org/licenses/by/4.0/). 